\title{
Seismic Fragility of Chinese Light-Gauge Steel Keel Gypsum Board Partition Walls
}

\author{
Duozhi Wang $\mathbb{D}^{1}{ }^{1}$ Xudong Zhi, ${ }^{2,3}$ Fangxu Zhu, ${ }^{4}$ and Yixing Wang ${ }^{1}$ \\ ${ }^{1}$ Key Laboratory of Earthquake Engineering and Engineering Vibration, Institute of Engineering Mechanics, \\ China Earthquake Administration, Harbin 150080, China \\ ${ }^{2}$ Key Lab of Structure Dynamic Behaviour and Control of the Ministry of Education, Harbin Institute of Technology, \\ Harbin 150090, China \\ ${ }^{3}$ Key Lab of Smart Prevention and Mitigation of Civil Engineering Disasters of Ministry of Industry and Information Technology, \\ Harbin Institute of Technology, Harbin 150090, China \\ ${ }^{4}$ China United Engineering Corporation Limited, Jinan 250000, China
}

Correspondence should be addressed to Duozhi Wang; wangdz@iem.ac.cn

Received 30 July 2020; Revised 27 April 2021; Accepted 21 May 2021; Published 1 June 2021

Academic Editor: Fabio Minghini

Copyright (C) 2021 Duozhi Wang et al. This is an open access article distributed under the Creative Commons Attribution License, which permits unrestricted use, distribution, and reproduction in any medium, provided the original work is properly cited.

\begin{abstract}
A quasi-static experimental program of light-gauge steel keel gypsum board partition walls (LSKGBPW) was carried out to evaluate the seismic damage phenomena, failure mechanisms, and fragility. The 15 specimens in five groups were designed per current Chinese codes and engineering practice. Then, three damage states were defined based on the damage and repair measures, and the fragility data of each group were presented, providing basic data for the estimation of seismic damage and consequential loss of nonstructural components.
\end{abstract}

\section{Introduction}

Structural damage (especially collapse) due to an earthquake often receives much attention. Accordingly, the mitigation of structural damage and human casualties has been regarded as the primary guiding principle in the seismic design codes of various countries and achieved remarkable results. However, the importance of nonstructural seismic safety has been largely ignored. In recent years, nonstructural seismic damages have led to enormous economic losses and impacted the resilience and postearthquake operations of buildings severely; hence, an increasing number of researchers have begun to pay attention to the seismic performance of nonstructural systems [1-5].

Nonstructural systems consist of three parts: the nonstructural building components, the mechanical, electrical, and plumbing (MEP) systems, and the housed instruments and equipment. Even if the structure is still usable, severe nonstructural seismic damage will not only cause very high economic losses but also seriously affect the postearthquake operation and reduce the seismic resilience of the building. The light-gauge steel keel gypsum board partition wall (LSKGBPW) is a widely used nonstructural building component in modern high-rise buildings. It is mainly composed of light-gauge steel keels, gypsum boards, and connectors. The LSKGBPW is a common component for partitioning large spaces and is easy to install and remove. However, this type of wall often suffers severe damage in earthquakes $[6,7]$, and the damage usually occurs under low-intensity earthquakes, not only causing a very large amount of property loss but also hindering postearthquake repair work [8]. Therefore, research on the seismic behavior of LSKGBPWs can improve the seismic performance of the component itself and help to enhance the seismic resilience of the building.

Research on the LSKGBPW has been conducted for a long time. Freeman and Rihal were among the earliest researchers, the performance of partition walls was studied experimentally $[9,10]$. McMullin and Merrick conducted tests to analyze the fragility of the wood frame gypsum board partition [11]. Reynaud et al. conducted tests with 17 light-gauge steel keel 
partition components with both length and width of 8 feet [12]. Their study showed that a gypsum board partition wall has lower shear strength than a plywood wall, and gypsum boards arranged transversely have a higher stiffness than those arranged vertically. Lee et al. carried out hysteresis tests on four full-scale LSKGBPWs [13] and investigated the effects of opening doors and return wall sections on the seismic performance of the wall. Davies et al. constructed an I-shaped LSKGBPW model and used it to investigate the performancebased seismic design method for nonstructural components. They defined three damage states and the provided the interstory drift ratio corresponding to each damage state based on the test results. Davies et al. designed full-scale LSKGBPWs and conducted tests [14, 15]. A total of 55 fullscale components with a variety of construction types were tested using the methods of in-plane loading, out-of-plane loading, quasi-static testing, and dynamic testing. A parametric hysteresis model of LSKGBPWs was established and used to simulate the in-plane stress performance of the wall. At last, the time-history analysis of an actual case was carried out, showing that the lateral stiffness of the building was improved by considering the contribution of LSKGBPWs. Padilla-Llano et al. performed axial tensile tests on light-gauge steel keels with $\mathrm{C}$ sections [16], including 12 cyclic tests, 12 monotonic compression tests, and 2 monotonic tensile tests, and evaluated the hysteretic behavior, strength degradation, and energy dissipation characteristics of the light-gauge steel keels with $\mathrm{C}$ sections. Amer et al. conducted research on LSKGBPWs with dampers [17]. Quasi-static tests were performed with a varying number of dampers, showing that the ultimate bearing capacity of the wall with dampers was greatly increased. Rahmanishamsi et al. conducted monotonic loading tests and hysteretic tests to study the performance of LSKGBPWs [18-21], including 31 gypsum board steel stud connection specimens, 33 steel stud-track connection specimens, and 22 track-floor connection specimens. In addition, a series of nonlinear plasticity models of partition wall joints were developed in OpenSees for numerical analysis of the wall. Later, Jenkins et al. conducted a shaking table test on a two-story one-bay steel frame-LSKGBPW and evaluated the performance of the LSKGBPW [22].

In this study, quasi-static tests on LSKGBPWs designed and installed based on Chinese codes and engineering practice are carried out, the damage phenomena and failure mechanisms are analyzed, three damage states are established based on damage phenomena and repair measures, the fragility data of each group are presented, and the effects of the partition wall-structure connection types on the performance and fragility of the partition wall are examined, providing basic data for the assessment of the seismic resilience of buildings considering nonstructural components.

\section{Experimental Scheme and Results}

2.1. Loading Apparatus. The tests were conducted in the structural laboratory of the Harbin Institute of Technology, with the aim to investigate seismic damage phenomena, failure mechanisms, and fragility of LSKGBPWs as well as the effects of the partition wall-structure connection type on the performance and fragility. The partition wall is a selfsupporting component that only bears its own weight. Therefore, it is necessary to design a test apparatus that is easy to load and does not affect the actual performance of the partition wall. The test apparatus includes a single-story steel frame, lateral displacement-limiting device, roof/floor concrete slab, and high-precision electrohydraulic servo actuator. There is no joint connection between the beam and the column of the steel frame, but a rolling is installed on the top of the column to support the steel beam. The reinforced concrete roof slab is fixed under the steel beam through the embedded parts, and the roof slab can be replaced during the test. Displacement-limiting devices are installed on both sides of the roof slab to ensure that the roof slab only moves in the horizontal loading direction. As the steel beam moves horizontally, it drives the roof slab to move in the same direction to load the partition wall. The floor slab is fixed on the ground by anchor bolts. The top and bottom parts of the partition wall are fixed to the roof slab and the floor slab, respectively. During the test, the lateral load is provided by the high-precision electrohydraulic servo actuator. The horizontal force transfer path is actuator $\longrightarrow$ steel beam $\longrightarrow$ roof slab $\longrightarrow$ partition wall [23]. Figures 1 and 2 show the I-shaped partition wall specimen tested.

2.2. Test Specimens. In the tests, the lateral resistance performance of LSKGBPWs under horizontal low-cycle reciprocating load was investigated. Figure 3 shows the view of the LSKGBPW design, and the construction details of the partition wall connection are shown in Figure 4. Table 1 lists the parameters of the specimens. All specimens met the code in the Light-gauge Steel Keel Gypsum Board Partition Wall and Suspended Ceiling standard [24]. The variables considered in the selection of the wall configurations include the following:

(1) The specimens were the independent I-shaped fullscale $(1: 1)$ partition walls with a height of $3 \mathrm{~m}$ and a span of $3 \mathrm{~m}$, as the top and bottom tracks connect with roof slab and floor slab, respectively, as illustrated in Figure 2.

(2) The detail of construction is illustrated in Figure 3.

(3) The size of a single gypsum board is $3 \mathrm{~m} \times 1.2 \mathrm{~m} \times 12 \mathrm{~mm}$ according to Chinese code GBT9775 (GB 2008).

(4) The U-shape track connects with the roof and floor slabs by shot pins, shot pin-backing plate, and expansion bolt, as illustrated in Figure 4. The specimens were distinguished to five groups by the connection types as listed in Table 1.

(5) The size of U-shape track is $75 \mathrm{~mm} \times 35 \mathrm{~mm} \times 0.55 \mathrm{~mm}$, as the size of C-shape steel stud is $73.5 \mathrm{~mm} \times 45 \mathrm{~mm} \times 0.55 \mathrm{~mm}$ as listed in Table 1.

(6) The U-shape track connects with the C-shape steed stud by self-tapping screw spacing $600 \mathrm{~mm}$. The 


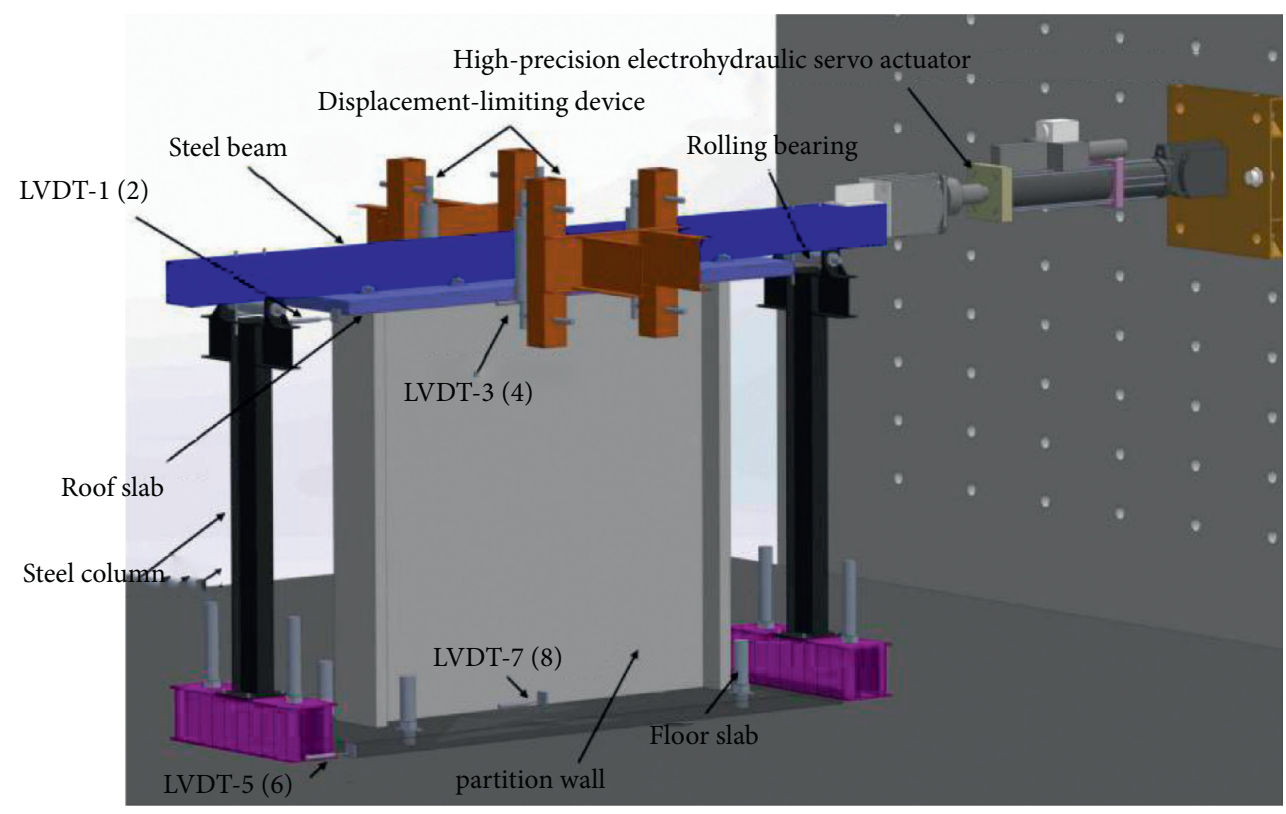

FIgURE 1: Loading apparatus.

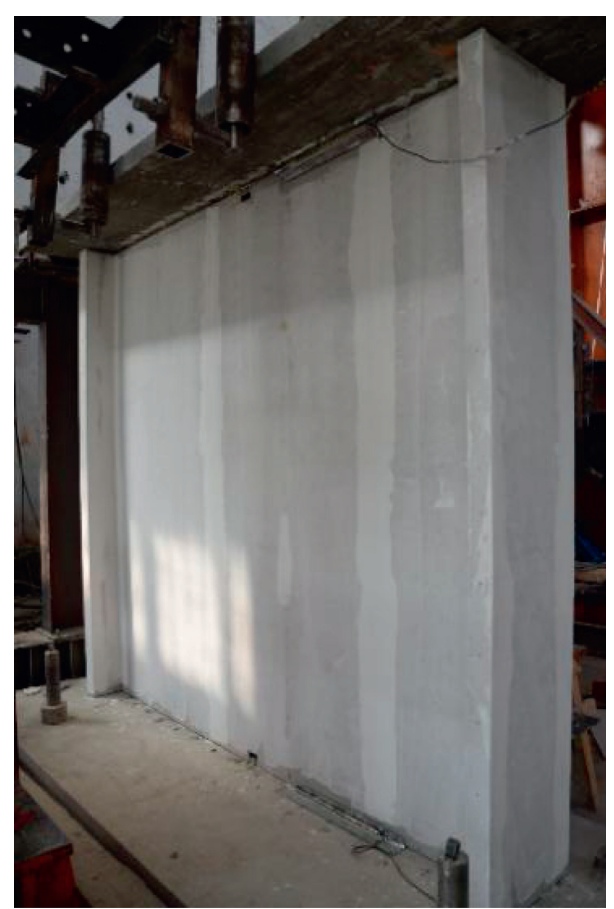

Figure 2: The specimen.

gypsum board connects with steel stud and track by self-tapping screw spacing $200 \mathrm{~mm}$.

(7) The gap was finished with caulking tapes and caulking plaster, as the external corner was protected with connerbead and caulking plaster.

2.3. Loading Regime. The tests were conducted in the structural laboratory of the Harbin Institute of Technology. A high-precision electrohydraulic servo actuator was used to apply a horizontal low-cycle reciprocating load parallel to the wall.

The loading regime was based on that proposed by Retamales et al, which was developed specifically to assess the fragility of nonstructural components that are sensitive to interstory drift [25]. In the method, the predicted interstory drift demand of nonstructural specimens is described by using a set of closed-form equations that should simultaneously satisfy the following conditions: (1) the ground response spectrum should be matched; (2) the target 


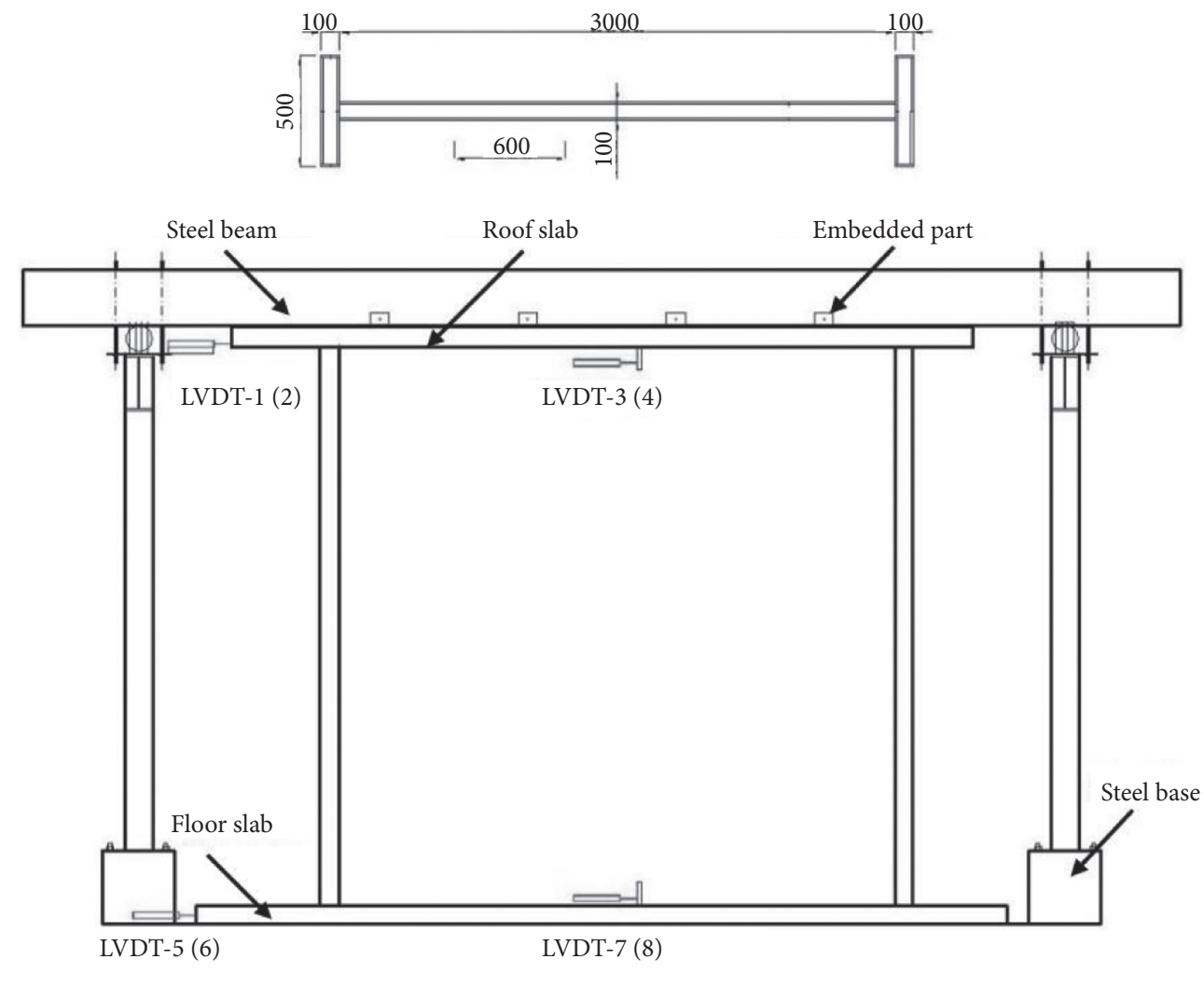

FIgURE 3: Section of the specimen design.

interstory drift ratio should be applied to the specimen; and (3) the number of story movement cycles applied to the specimen should be the same as that in actual seismic records. The displacement record generated based on this loading regime is shown in Figure 5. The LSKGBPW has a relatively low lateral stiffness, and its damage process is sensitive to the interstory drift ratio. This loading regime is characterized by many steps and small increments per step and can record in detail the variation processes of the interstory drift ratio and failure of the specimens, satisfying the needs of fragility research. The loading regime uses displacement control throughout the entire process with the minimum displacement increment of $0.5 \mathrm{~mm}$. As loading progresses, the displacement increment per step increases gradually. In the tests, displacement sensors are placed in the middle of the reinforced concrete roof and floor to measure the displacement and calculate the interstory drift ratio.

2.4. Experimental Results. The damage characteristics of the LSKGBPW are described in detail in Table 2 and Figure 6. The damage processes and characteristics of groups $\mathrm{A}, \mathrm{B}$, and $C$ are similar, reflecting the influence of the shot pin distance, while those of groups C, D, and E reflect the effect of the connection type on the damage phenomena.

Based on the damage characteristics of groups A, B, and $\mathrm{C}$, it is found that, when the distance between shot pins was small, the damage on the partition wall-structure connection was delayed under the same load. Figures $7(\mathrm{a}) \sim 7$ (c) show the hysteresis loops observed for specimen in group A to $\mathrm{C}$, respectively. Then, according to the damage characteristics of the specimens in group D, the backing plate strengthened the local track and could prevent it from tearing effectively. However, the damage to the partition wall-structure connection was dominated by shearing of the shot pins after adding the backing plates, while the partition wall-structure connection was affected by both the strength of the track and the strength of the shot pins. Therefore, the backing plate could not strengthen the partition wall-structure effectively, and the damage phenomena of the specimens in group $\mathrm{D}$ were similar to groups A, B, and C. Figure 7(d) shows the hysteresis loops observed for specimen in group D.

In group E, first, the self-tapping screws at the edge of gypsum board were loosened. Then, the gypsum boards at the corner were crushed, and the self-tapping screws were loosened and pulled out severely. Crack occurred at the connection of two gypsum boards on the longitudinal wall. Finally, the steel stud buckled severely, or the gypsum boards were separated from each other on the longitudinal wall, and the specimen was failed. Compared to other specimens, the specimens of group $\mathrm{E}$ did not show any damage on the partition wall-structure connection, due to the strong expansion bolt, but the more self-tapping screws loosened or were pulled out, and the steel stud buckled. The damage phenomena of group E were different from other specimens, showing that strengthening the partition wall-structure connection could change the damage phenomena of the partition wall. Figure 7(e) shows the hysteresis loops observed for specimen in group $\mathrm{E}$. 


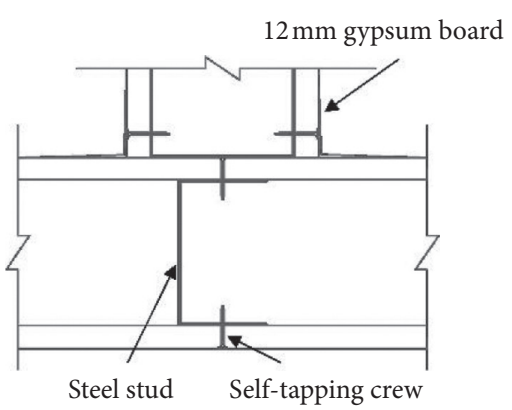

(a)

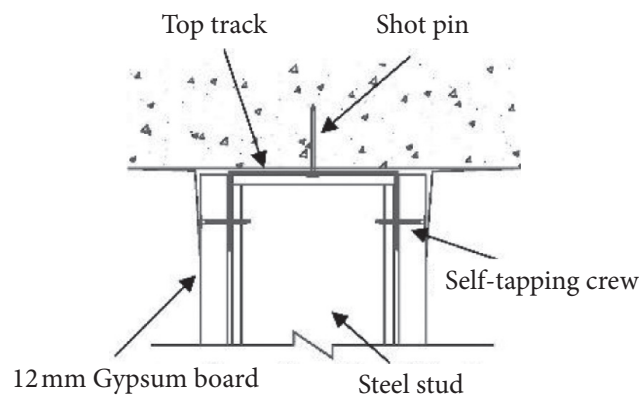

(c)

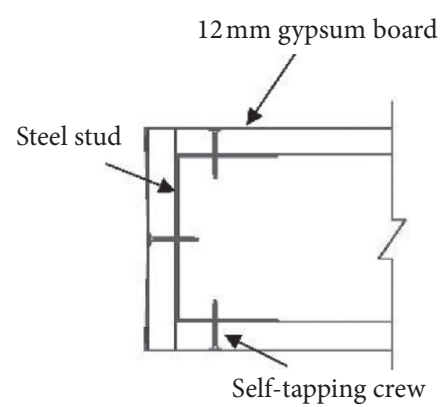

(b)

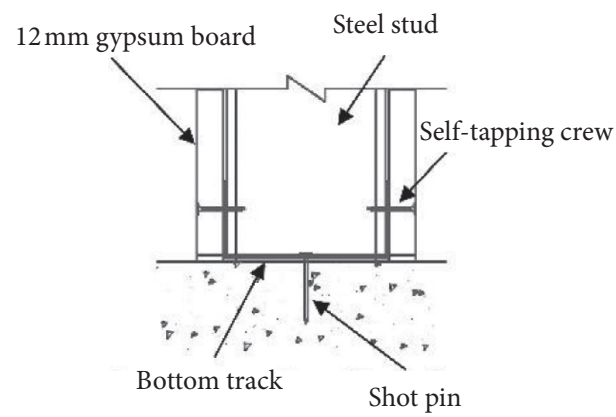

(d)

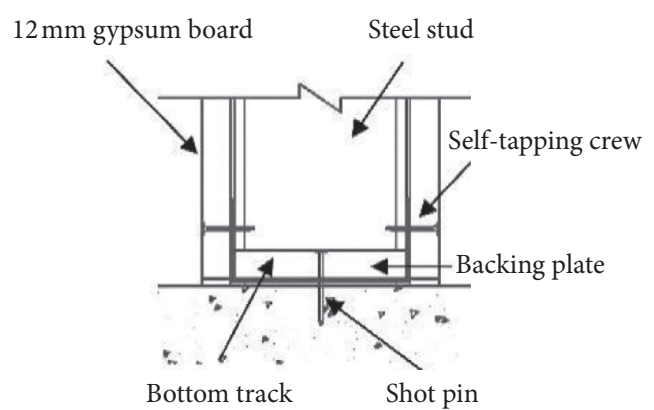

(e)

Figure 4: Detail of construction (a) T joint. (b) The edge joint. (c) The top track joint. (d) The bottom track joint. (e) The bottom track joint with backing plate.

\section{Seismic Fragility Analysis}

In accordance with the fragility test method in the ATC-58 Guidelines for the Seismic Performance Assessment of Buildings, the interstory drift ratio was used as the demand parameter for the fragility analysis of the nonstructural partition walls, quasi-static tests were conducted to obtain the data of the damage process of the LSKGBPWs, and the fragility curves of each group of specimens were calculated and comparatively analyzed.

To perform the fragility analysis, the damage phenomena observed during the tests were classified into three damage states in Table 3. The damage states of the partition wall were defined based on its damage characteristics and the corresponding repair measures. The damage state $\mathrm{DS}_{1}$ refers to damage to the decorative surface only, the damage state $\mathrm{DS}_{2}$ means that part of the LSKGBPW needs to be replaced, and damage state $\mathrm{DS}_{3}$ corresponds to the removal of the entire partition wall. Table 4 lists the measured interstory drift ratios corresponding to each damage state.
The fragility function $F_{\mathrm{dm}}$ is defined as the probability that the LSKGBPW attains or exceeds the damage state $\mathrm{dm}$ given the interstory drift ratio edp. This function is expressed by a lognormal distribution as follows:

$$
F_{\mathrm{dm}}(\mathrm{edp})=\Phi\left(\frac{\ln \left(\mathrm{edp} / x_{m}\right)}{\beta}\right)
$$

where $\Phi$ is the cumulative standard normal (Gaussian) distribution function, $x_{m}$ is the mean of this distribution, and $\beta$ is the logarithmic standard deviation of this distribution. Since the lognormal distribution model is very capable of fitting the failure data of various structural and nonstructural components, it has been widely and effectively used as a fragility function model in seismic fragility analysis [26]. Each damage state of each group of specimens with different construction configurations corresponds to a fragility function curve defined by $x_{m}$ and $\beta$, as shown in equations (2) to (5). The maximum likelihood estimation (MLE) method can be used to calculate the MLE values of $x_{m}$ 
TABLE 1: Information of partition wall specimens.

\begin{tabular}{|c|c|c|c|c|c|c|}
\hline Group & No. & $\begin{array}{c}\text { Connection type } \\
\text { between track and floor } \\
\text { slab }\end{array}$ & $\begin{array}{l}\text { Connection distance } \\
\text { between shot pins }(\mathrm{mm})\end{array}$ & $\begin{array}{l}\text { C-shaped steel stud } \\
\mathrm{mm} \times \mathrm{mm} \times \mathrm{mm}\end{array}$ & $\begin{array}{l}\text { U-shaped track } \\
\mathrm{mm} \times \mathrm{mm} \times \mathrm{mm}\end{array}$ & Gypsum board \\
\hline A & $\begin{array}{l}\mathrm{A} 1 \\
\mathrm{~A} 2 \\
\mathrm{~A} 3\end{array}$ & Shot pin & 600 & $73.5 \times 45 \times 0.55$ & $75 \times 35 \times 0.55$ & $3 \mathrm{~m} \times 1.2 \mathrm{~m} \times 12 \mathrm{~mm}$ \\
\hline B & $\begin{array}{l}\mathrm{B} 1 \\
\mathrm{~B} 2 \\
\mathrm{~B} 2 \\
\end{array}$ & Shot pin & 400 & $73.5 \times 45 \times 0.55$ & $75 \times 35 \times 0.55$ & $3 \mathrm{~m} \times 1.2 \mathrm{~m} \times 12 \mathrm{~mm}$ \\
\hline $\mathrm{C}$ & $\begin{array}{l}\mathrm{C} 1 \\
\mathrm{C} 2 \\
\mathrm{C} 3\end{array}$ & Shot pin & 200 & $73.5 \times 45 \times 0.55$ & $75 \times 35 \times 0.55$ & $3 \mathrm{~m} \times 1.2 \mathrm{~m} \times 12 \mathrm{~mm}$ \\
\hline $\mathrm{D}$ & $\begin{array}{l}\text { D1 } \\
\text { D2 } \\
\text { D3 }\end{array}$ & Shot pin-backing plate & 200 & $73.5 \times 45 \times 0.55$ & $75 \times 35 \times 0.55$ & $3 \mathrm{~m} \times 1.2 \mathrm{~m} \times 12 \mathrm{~mm}$ \\
\hline $\mathrm{E}$ & $\begin{array}{l}\text { E1 } \\
\text { E2 } \\
\text { E3 }\end{array}$ & Expansion bolt & 200 & $73.5 \times 45 \times 0.55$ & $75 \times 35 \times 0.55$ & $3 \mathrm{~m} \times 1.2 \mathrm{~m} \times 12 \mathrm{~mm}$ \\
\hline
\end{tabular}

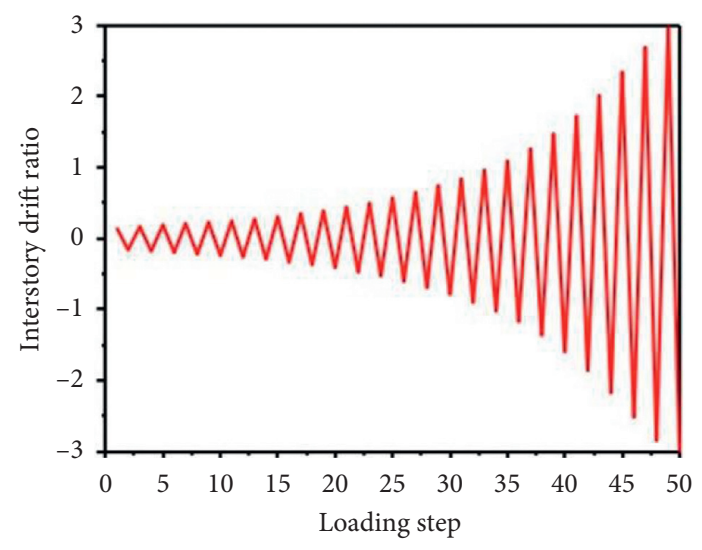

FIgURE 5: Loading regime.

TABLE 2: Failure patterns.

\begin{tabular}{|c|c|c|c|c|}
\hline Group & $\begin{array}{l}\text { Number of } \\
\text { specimens }\end{array}$ & Connection type & $\begin{array}{l}\text { Connection } \\
\text { distance }(\mathrm{mm})\end{array}$ & Damage phenomena \\
\hline $\bar{A}$ & 3 & Shot pin & 600 & $\begin{array}{l}\text { Cracks in the gypsum boards of the transverse walls on both sides, } \\
\text { Figure } 6(\mathrm{a}) \text {; cracks in the internal corner, Figure } 6(\mathrm{~b}) \text {; loose, dislodged, }\end{array}$ \\
\hline B & 3 & Shot pin & 400 & $\begin{array}{c}\text { sheared shot pins at the connection, Figure } 6(\mathrm{c}) \text {; tearing of the track, } \\
\text { Figure } 6(\mathrm{~d}) \text {; separation of the transverse and longitudinal wall, } \\
\text { Figure } 6(\mathrm{e}) \text {. }\end{array}$ \\
\hline $\mathrm{C}$ & 3 & Shot pin & 200 & \\
\hline $\mathrm{D}$ & 3 & $\begin{array}{l}\text { Shot pin-backing } \\
\text { plate }\end{array}$ & 200 & $\begin{array}{l}\text { Cracks in the gypsum boards of the transverse walls on both sides; } \\
\text { cracks in the internal corner; loosening, dislodging, and shearing off of } \\
\text { the shot pins at the connection; tearing of the track; separation of the } \\
\text { transverse and longitudinal walls; cracking between the gypsum boards } \\
\text { of the longitudinal wall, Figure } 6(\mathrm{f}) \text {. }\end{array}$ \\
\hline $\mathrm{E}$ & 3 & Expansion bolt & 200 & $\begin{array}{l}\text { Cracks appearing in the transverse walls on both sides, cracks in the } \\
\text { internal corner, cracks between the gypsum boards of the longitudinal } \\
\text { wall, loosening and dislodging of the self-tapping screws between the } \\
\text { gypsum board and the keel, Figure } 6(\mathrm{~g}) \text {, local crushing of the gypsum } \\
\text { boards, Figure } 6(\mathrm{~h}) \text {, local separation of the gypsum board and keel, } \\
\text { Figure 6(i), severe local buckling of the steel stud, Figure } 6(\mathrm{j}) \text {. }\end{array}$ \\
\hline
\end{tabular}




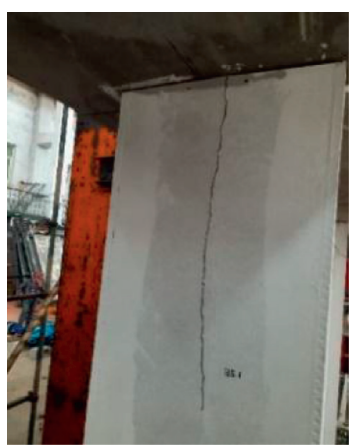

(a)

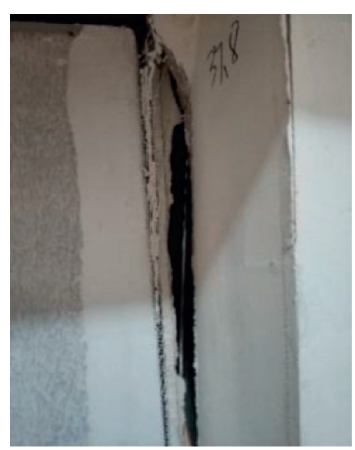

(e)

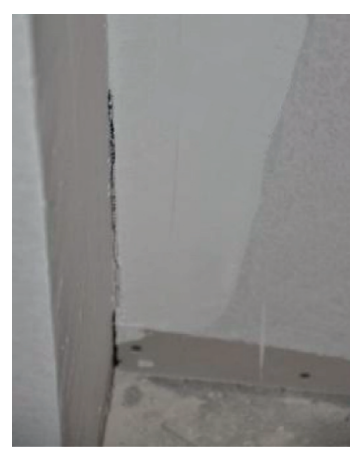

(b)

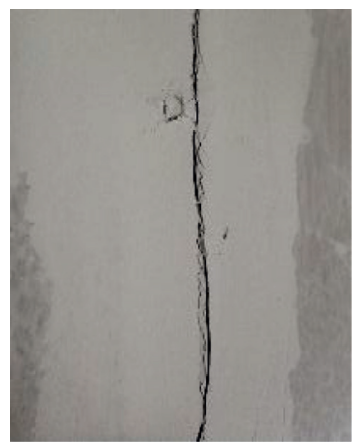

(f)

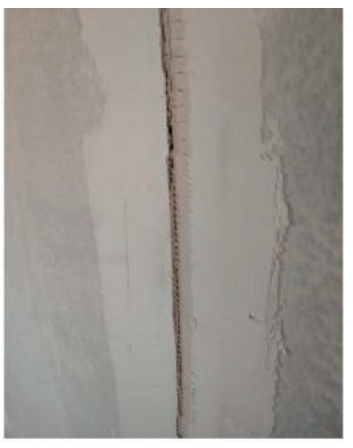

(i)

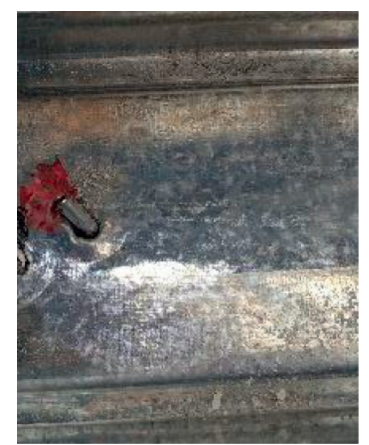

(c)

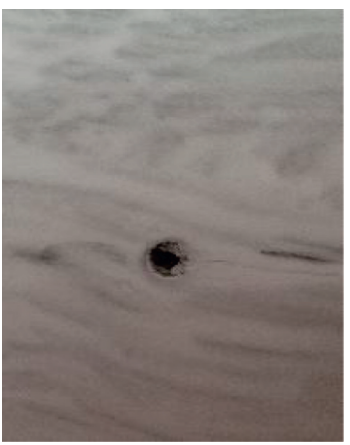

(g)

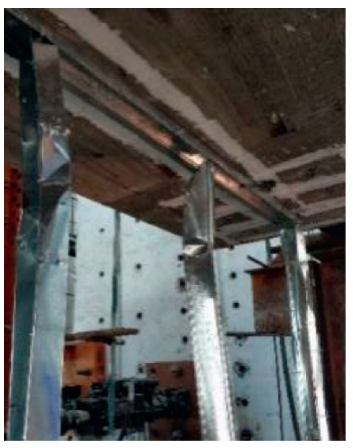

(j)

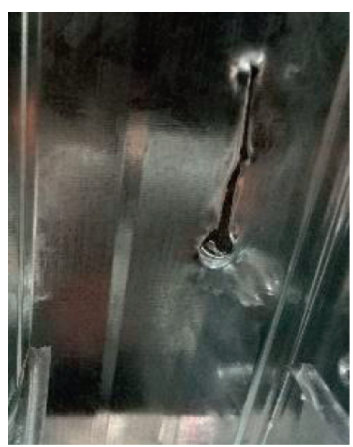

(d)

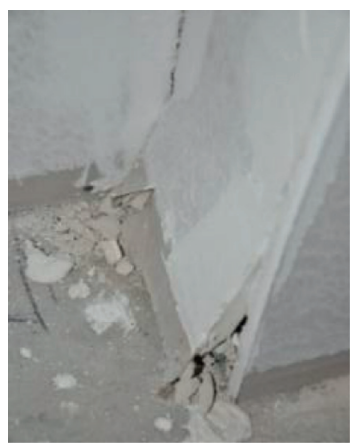

(h)

Figure 6: . Damage phenomena. (a) Crack of the gypsum boards in the transverse wall. (b) Crack at the internal corner. (c) Loosening of a shot pin. (d) Tearing of the track at the shot pin connection. (e) Separation of the transverse wall from the longitudinal wall. (f) Crack at the connection of the gypsum boards of the longitudinal wall. (g) Pulling out self-tapping screw in the gypsum board. (h) Crushing of the gypsum board. (i) Separation of the gypsum board from the steel stud. (j) Severe buckling of the steel stud.

and $\beta$ according to the specimen data obtained experimentally. Table 5 gives the equations for calculating the MLE values of $x_{m}$ and $\beta$ :

$$
\begin{aligned}
\mu & =\frac{1}{M} \sum_{i=1}^{M} \ln r_{i}^{j}, \\
\sigma^{2} & =\frac{1}{M} \sum_{i=1}^{M}\left(\ln r_{i}^{j}-\mu\right)^{2}, \\
\beta & =\sqrt{\sigma^{2}}, \\
x_{m}^{j} & =e^{\mu+\sigma^{2}},
\end{aligned}
$$

where $j=1,2$, and 3 denote the three damage states of a specimen, $i$ represents the $i$ th specimen in a group of specimens for fragility analysis, $r_{i}^{j}$ denotes the interstory drift ratio that triggers the $j$ th damage state of the $i$ th specimen, and $M$ is the number of specimens in a group of specimens for fragility analysis, where $M=3$ in this study. The fragility curves are shown in Figures 8-12.

The fragility curves of the 5 groups of specimens are comparatively analyzed. There are three types of partition wall-structure connections (the shot pin connections, the shot pin-backing plate connections, and the expansion bolt connections) in the tests, and the connection distance of shot pin was set to $200 \mathrm{~mm}, 400 \mathrm{~mm}$, and $600 \mathrm{~mm}$. Moreover, the damage of the specimen can be divided into two types by the location, partition wall-structure connection damage, and 


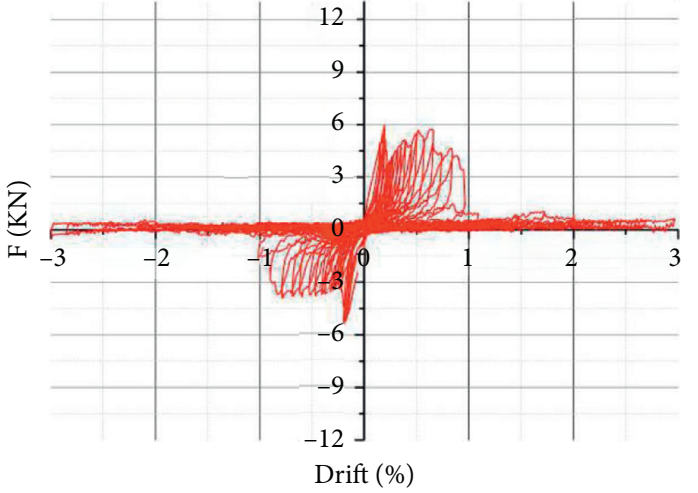

$-\mathrm{A}$

(a)

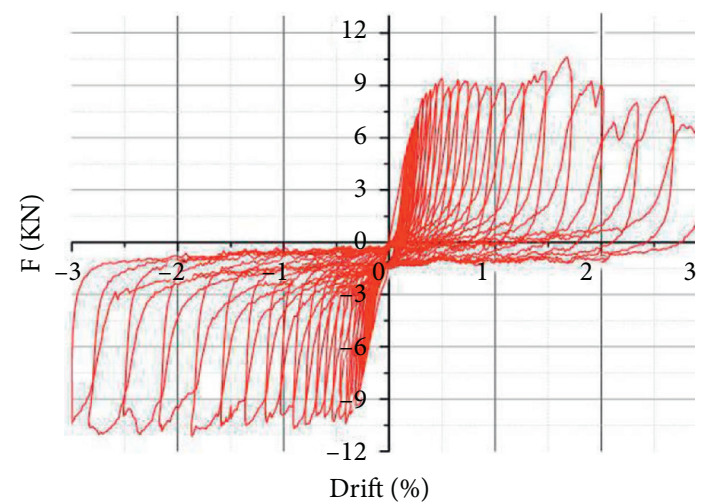

C

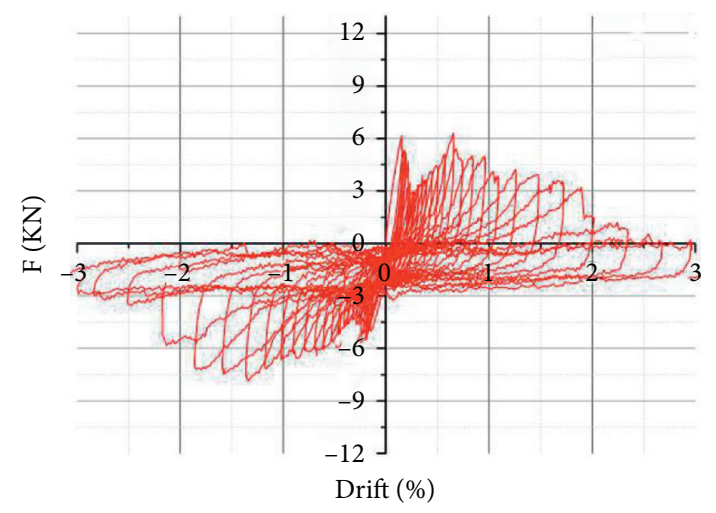

$-\mathrm{B}$

(b)

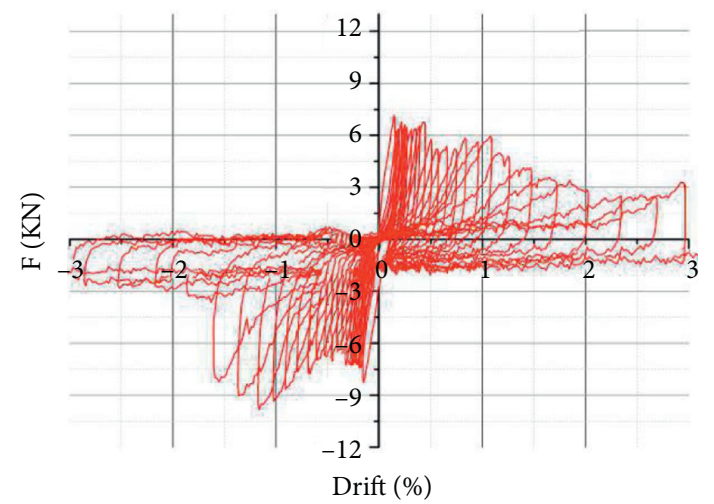

$-\mathrm{D}$

(d)

(c)

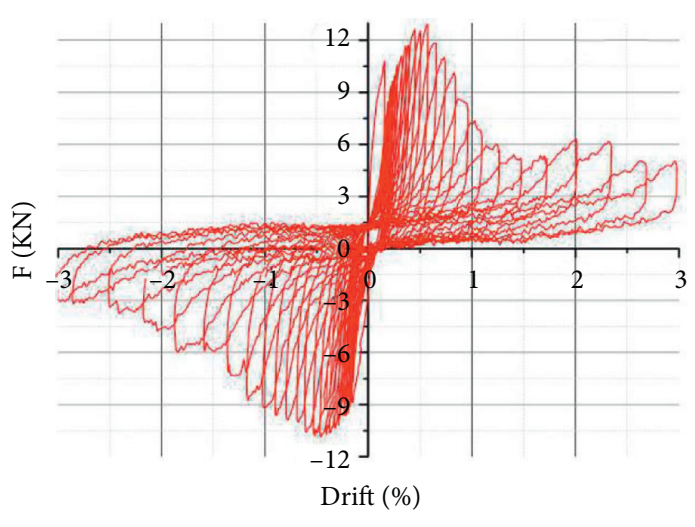

$-\mathrm{E}$

(e)

Figure 7: Hysteresis behaviors of specimens. (a) Specimen in group A. (b) Specimen in group B. (c) Specimen in group C. (d) Specimen in group D. (e) Specimen in group E.

partition wall damage; and the two types of damage coexisted in the tests.

When the partition wall-structure connection was strengthened, the energy was transferred to the partition wall by the connection effectively, which aggravated the damage of the partition wall. Conversely, when the partition wallstructure connection was weak, the damage to the partition wall-structure connection became more severe. As the energy was dissipated by the damaged connection, the energy transferred to the partition wall was reduced, which led to little damage to the partition wall.

It was found that an appropriate reduction of shot pin distance could improve the performance of the partition wall-structure connection. However, the performance of the specimen did not increase monotonously with the reduction of shot pin distance. For example, as the shot pin distance 
TABLE 3: Division of damage states of LSKGBPWs.

\begin{tabular}{lcc}
\hline $\begin{array}{l}\text { Damage } \\
\text { state }\end{array}$ & \multicolumn{1}{c}{ Description of damage } & Repair measure \\
\hline DS & $\begin{array}{l}\text { Cracks starting in the gypsum boards, slipping of the partition } \\
\text { wall-structure connection, loosening of the self-tapping screws } \\
\text { around the gypsum board. Cracks in the middle of the gypsum } \\
\text { boards of the transverse wall. }\end{array}$ & $\begin{array}{c}\text { Replacement of the corner beads, caulking tapes, and } \\
\text { loose self-tapping screws and surface plastering. }\end{array}$ \\
\hline DS & $\begin{array}{c}\text { Cracks between the gypsum boards of the longitudinal wall, } \\
\text { crushing of the gypsum boards at the wall corner, failure of the self- } \\
\text { tapping screws around the gypsum board or loosening of the self- } \\
\text { tapping screws in the middle of the gypsum boards. }\end{array}$ & $\begin{array}{c}\text { Replacement of the entire gypsum board and } \\
\text { reinstallation of the self-tapping screws around the } \\
\text { partition wall. }\end{array}$ \\
\hline DS & $\begin{array}{l}\text { Failure of the partition wall-structure connection, separation of the } \\
\text { gypsum board from the steel stud, local bending, and plastic hinge } \\
\text { occurring in the steel stud. }\end{array}$ & $\begin{array}{c}\text { Removal of the damaged partition wall and installation of } \\
\text { a new one. }\end{array}$ \\
\hline
\end{tabular}

TABLE 4: Specimen damage state and interstory drift ratio (unit: \%).

\begin{tabular}{|c|c|c|c|c|c|c|c|c|c|c|c|c|c|c|c|c|}
\hline $\begin{array}{l}\text { Damage } \\
\text { state }\end{array}$ & Damage characteristics & A1 & $\mathrm{A} 2$ & A3 & B1 & B2 & B3 & $\mathrm{C} 1$ & $\mathrm{C} 2$ & C3 & D1 & D2 & D3 & E1 & E2 & E3 \\
\hline \multirow{4}{*}{$\mathrm{DS}_{1}$} & Cracks starting & 0.57 & 0.29 & 0.22 & 0.65 & 0.44 & 0.20 & 0.31 & 0.44 & 0.26 & 0.35 & 0.25 & 0.23 & 0.29 & 0.25 & 0.29 \\
\hline & $\begin{array}{l}\text { Slipping of the partition wall-structure } \\
\text { connection }\end{array}$ & 0.25 & 0.32 & 0.20 & 0.25 & 0.61 & 0.25 & 0.47 & 0.35 & 0.50 & 0.39 & 0.41 & 0.35 & 一 & 一 & 一 \\
\hline & $\begin{array}{l}\text { Loosening of the self-tapping screws } \\
\text { around the gypsum board }\end{array}$ & - & - & - & - & - & - & - & - & 0.79 & 0.53 & - & - & 0.57 & 0.39 & 0.44 \\
\hline & Minimum drift level triggering $\mathrm{DS}_{1}$ & 0.25 & 0.29 & 0.20 & 0.25 & 0.44 & 0.20 & 0.31 & 0.35 & 0.26 & 0.35 & 0.25 & 0.23 & 0.29 & 0.25 & 0.29 \\
\hline \multirow{5}{*}{$\mathrm{DS}_{2}$} & $\begin{array}{l}\text { Cracks in the middle of the gypsum } \\
\text { boards of the transverse wall }\end{array}$ & 0.74 & 0.96 & 0.83 & 1.02 & 1.09 & 0.90 & 0.90 & 0.84 & 0.79 & 1.72 & 1.26 & 1.36 & - & - & - \\
\hline & $\begin{array}{l}\text { Cracks between the gypsum boards of } \\
\text { the longitudinal wall }\end{array}$ & - & - & - & 1.02 & 1.86 & 1.59 & 1.72 & 1.59 & 1.36 & 0.90 & 1.02 & 1.02 & 1.36 & 0.87 & 1.17 \\
\hline & $\begin{array}{c}\text { Crushing of the gypsum boards at the } \\
\text { wall corner }\end{array}$ & - & - & - & - & 一 & - & 一 & - & - & - & - & - & 0.84 & 0.74 & 1.09 \\
\hline & $\begin{array}{l}\text { Failure of the self-tapping screws } \\
\text { around the gypsum board or loosening } \\
\text { of the self-tapping screws in the } \\
\text { middle of the gypsum boards }\end{array}$ & - & - & - & - & - & - & - & - & - & - & 1.72 & - & 1.26 & 1.59 & 1.72 \\
\hline & Minimum drift level triggering $\mathrm{DS}_{2}$ & 0.74 & 0.96 & 0.83 & 1.02 & 1.09 & 0.90 & 0.90 & 0.84 & 0.79 & 0.90 & 1.02 & 1.02 & 0.84 & 0.74 & 1.09 \\
\hline \multirow{4}{*}{$\mathrm{DS}_{3}$} & $\begin{array}{l}\text { Failure of the partition wall-structure } \\
\text { connection }\end{array}$ & 0.90 & 1.72 & 0.90 & 1.26 & 2.34 & 0.84 & 2.01 & 1.26 & 1.09 & 0.90 & 1.47 & 1.17 & - & - & - \\
\hline & $\begin{array}{l}\text { Separation of the gypsum board from } \\
\text { the steel stud }\end{array}$ & - & - & - & - & - & - & - & 一 & 一 & - & 一 & - & 0.90 & 1.12 & 1.47 \\
\hline & $\begin{array}{l}\text { Local bending and plastic hinge } \\
\text { occurring in the steel stud }\end{array}$ & - & - & - & - & - & - & - & - & - & - & - & - & 1.36 & 1.26 & 1.09 \\
\hline & Minimum drift level triggering $\mathrm{DS}_{3}$ & 0.90 & 1.72 & 0.90 & 1.26 & 2.34 & 0.84 & 2.01 & 1.26 & 1.09 & 0.90 & 1.47 & 1.17 & 0.90 & 1.12 & 1.09 \\
\hline
\end{tabular}

Note: data in the table are interstory drift ratios (unit: \%).

decreased from $400 \mathrm{~mm}$ to $200 \mathrm{~mm}$, although the damage to the partition wall-structure connection was reduced, the damage of the specimen was not improved effectively.

The shot pin-backing plate connections were used in group $\mathrm{D}$ to investigate the influence of the backing plate on the performance of specimen. However, compared with the fragility data of group $\mathrm{C}$, it shows that the backing plate did not strengthen the partition wall-structure connection effectively. The damage to the partition wall-structural connection resulted from both shot pin damage and track tearing. Although the backing plate could reduce the damage caused by the tearing of the track, it did not protect the shot pins effectively. Therefore, the backing plate could only change the damage phenomena of the partition wallstructure joint and improve bearing capacity of specimen effectively.

Compared to other specimens, the specimens in group $\mathrm{E}$ were constructed with expansion bolt connections, leading to the highest strength of the partition wall-structure joint, hence no failure of the joints in the tests. However, the specimen did not show improved performance. When the partition wall-structure joint was strengthened, more energy was transferred to the partition wall. Therefore, the specimen in group $\mathrm{E}$ did not appear better performance than others.

The fragility curves $\mathrm{DS}_{2}$ and $\mathrm{DS}_{3}$ are crossing in groups $\mathrm{A}, \mathrm{B}$, and $\mathrm{D}$. The fragility curve is calculated by cumulative 
TABle 5: Summary of fragility curve parameters.

\begin{tabular}{lcccccccccc}
\hline \multirow{2}{*}{ Damage state } & \multicolumn{2}{c}{$\mathrm{A}$} & \multicolumn{2}{c}{$\mathrm{B}$} & \multicolumn{2}{c}{$\mathrm{C}$} & \multicolumn{2}{c}{$\mathrm{D}$} & \multicolumn{2}{c}{$\mathrm{E}$} \\
& $x_{m}$ & $\beta$ & $x_{m}$ & $\beta$ & $x_{m}$ & $\beta$ & $x_{m}$ & $\beta$ & $x_{m}$ & $\beta$ \\
\hline $\mathrm{DS}_{1}$ & 0.257 & 0.192 & 0.296 & 0.332 & 0.307 & 0.122 & 0.277 & 0.181 & 0.277 \\
$\mathrm{DS}_{2}$ & 0.843 & 0.107 & 1.003 & 0.079 & 0.843 & 0.053 & 0.980 & 0.059 & 0.890 & 0.161 \\
$\mathrm{DS}_{3}$ & 1.170 & 0.305 & 1.479 & 0.421 & 1.451 & 0.261 & 1.180 & 0.200 & 1.163 & 0.201 \\
\hline
\end{tabular}

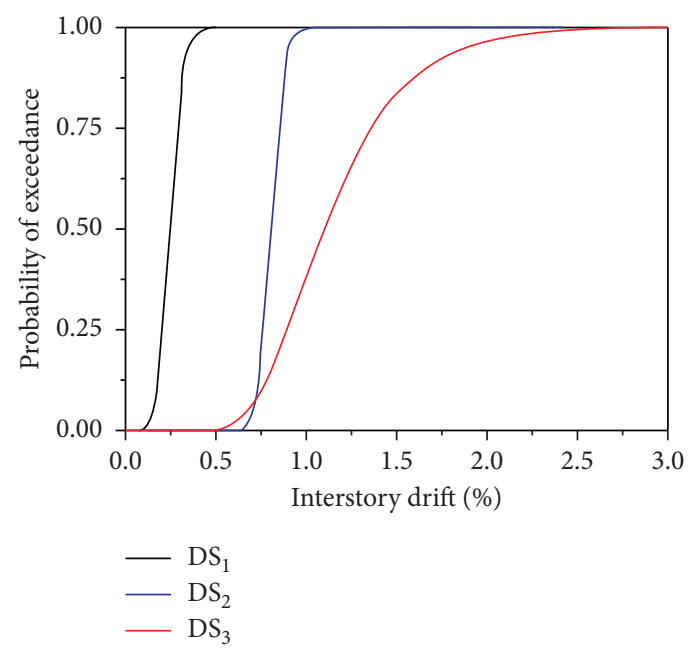

FIgURE 8: Fragility curves for group A.

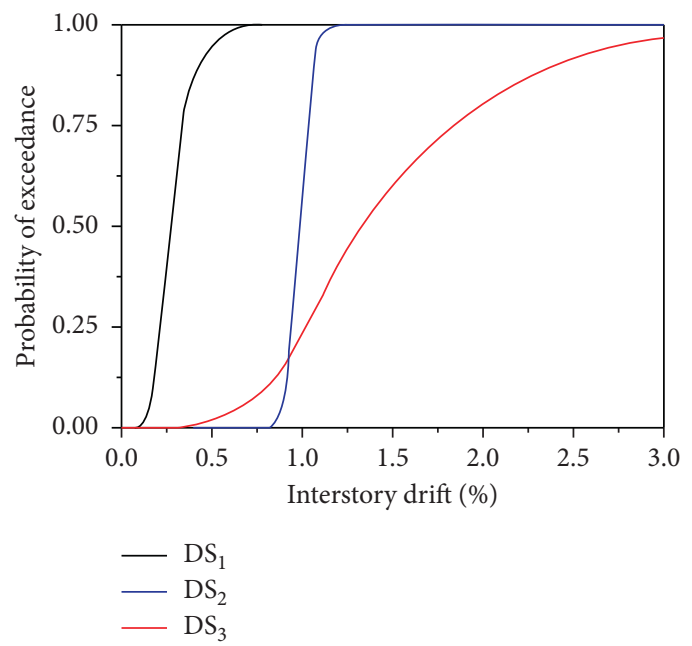

FIgURE 9: Fragility curves for group B.

standard normal (Gaussian) distribution function, as the values of edp range from 0 to 3 . As long as $x_{m}$ and $\beta$ satisfy certain conditions, the curve may cross. There may be a complete damage of $\mathrm{DS}_{3}$ following the slight damage of $\mathrm{DS}_{1}$ for construction of groups A, B, and D. It belongs to brittle failure. In addition, subsequent studies will increase the 


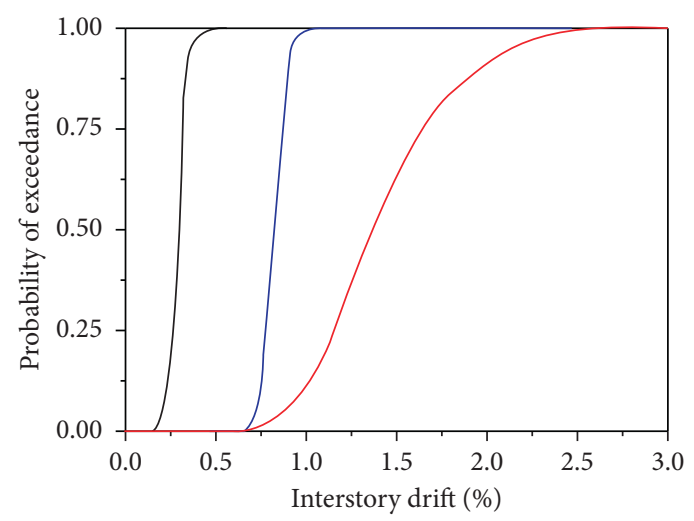

- $\mathrm{DS}_{1}$

- $\mathrm{DS}_{2}$

$-\mathrm{DS}_{3}$

Figure 10: Fragility curves for group C.

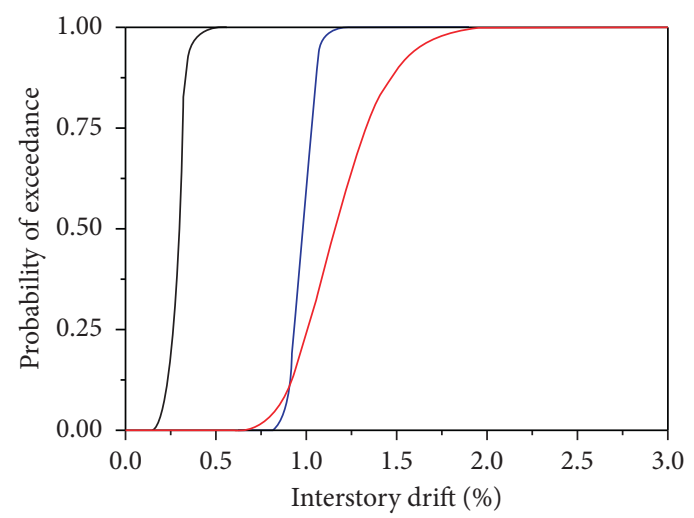

- $\mathrm{DS}_{1}$

$-\mathrm{DS}_{2}$

$-\mathrm{DS}_{3}$

Figure 11: Fragility curves for group D.

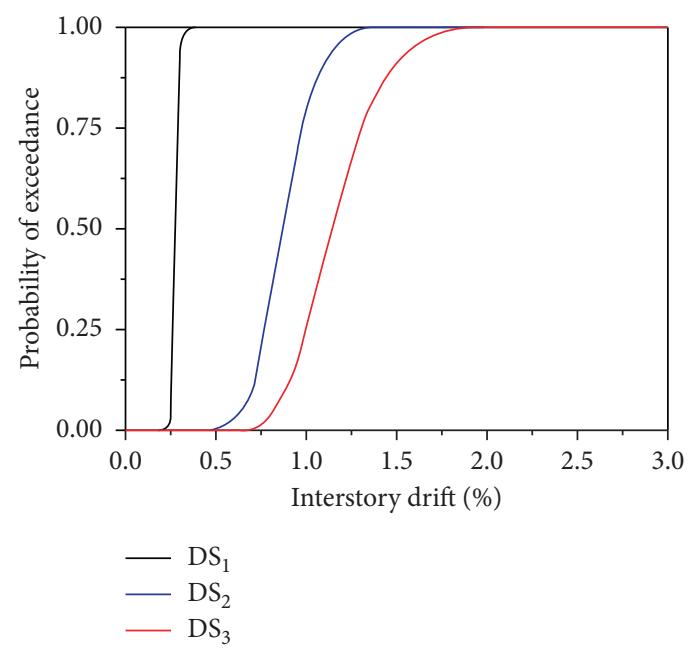

FIgURE 12: Fragility curves for group E. 
number of specimens and continue to examine the crossing of fragility curves.

\section{Conclusion}

The quasi-static tests were carried out on full-scale lightgauge steel keel gypsum board partition wall (LSKGBPW) specimens in the structural laboratory of the Harbin Institute of Technology. A total of 15 I-shaped partition wall specimens in five groups were designed. Among them, four groups of specimens were designed per the construction methods in the current Chinese codes, and one group of specimens was designed according to the strengthening method used in engineering commonly.

The five groups of specimens differed in the partition wall-structure connection, for which the damage phenomenon of the specimens was different. The damage of the specimens with shot pin connection or shot pin-backing plate connection (groups A, B, C, and D) was different from group $\mathrm{E}$ with expansion bolt connection. More partition wall-structure joint damage occurred in groups A to D, as more partition wall damage occurred in the group E.

Three damage states are defined according to the damage level and repair measures, and the fragility data for groups with different types of construction are provided, offering basic data for the assessment of the seismic performance and resilience of buildings considering nonstructural components. First, an appropriate decrease of shot pin distance could improve the strength of the partition wall-structure connection, thereby improving the seismic performance of the specimen. However, the performance of the specimen was not improved monotonously as the shot pin distance decreased. The specimen appeared the similar better performance when the shot pin distance of the specimens was reduced from $400 \mathrm{~mm}$ to $200 \mathrm{~mm}$. Then, the backing plate could change the damage phenomenon of the partition wallstructure joint, but it could not improve the performance effectively. Moreover, expansion bolt connection can change the damage location but did not improve the performance of the specimen.

\section{Data Availability}

The datasets generated during and/or analysed during the current study are available from the corresponding author on reasonable request.

\section{Conflicts of Interest}

The authors declare that they have no conflicts of interest.

\section{Acknowledgments}

This study was supported by the Scientific Research Fund of Institute of Engineering Mechanics, China Earthquake Administration (grant nos. 2018D07, 2018B11, and 2019EEEVL0304), and China Scholarship Council, and the authors extend their sincere gratitude for the support.

\section{References}

[1] F. Andre, P. Daniele, B. Emanuele, B. Clemens, and P. Roberto, "Effect of cyclic loading protocols on the experimental seismic performance evaluation of suspended piping restraint installations," International Journal of Pressure Vessels and Piping, vol. 166, pp. 61-71, 2018.

[2] D. Perronr, E. Brunesi, A. Filiatrault, and R. Nascimbene, "Probabilistic estimation of floor response spectra in masonry infilled reinforced concrete building portfolio-science direct," Engineering Structures, vol. 202, 2020.

[3] D. Perrone, E. Brunesi, A. Filiatrault et al., "Seismic numerical modelling of suspended piping trapeze restraint installations based on component testing," Bulletin of Earthquake Engineering, vol. 18, no. 6, 2020.

[4] D. Wang, J. Dai, Z. Qu, and N. Xiaoqing, "Shake table tests of suspended ceilings to simulate the observed damage in the Ms7.0 Lushan earthquake, China," Earthquake Engineering and Engineering Vibration, vol. 15, no. 2, pp. 239-249, 2016.

[5] D. Wang, J. Dai, and X. Ning, "Shaking table tests of typical B-ultrasound model hospital room in a simulation of the Lushan earthquake," Bulletin of the New Zealand Society for Earthquake Engineering, vol. 49, no. 1, pp. 116-124, 2016.

[6] J. I. Restrepo and A. M. Bersofsky, "Performance characteristics of light gage steel stud partition walls," Thin-Walled Structures, vol. 49, no. 2, pp. 317-324, 2011.

[7] X. Wang and E. Pantoli, "Seismic performance of cold-formed steel wall systems in a full-scale building," Journal of Structural Engineering, vol. 141, no. 10, pp. 1-11, 2015.

[8] R. L. Wood and T. C. Hutchinson, "Design-oriented model for capturing the in-plane seismic response of partition walls," Journal of Structural Engineering, vol. 140, no. 6, pp. 401-423, 2014.

[9] S. A. Freeman, "Racking tests of high-rise building partitions," Journal of the Structural Division, vol. 103, no. 8, pp. 1673$1685,1976$.

[10] S. S. Rihal, "Behavior of non-structural building partitions during earthquakes," Edited by S. Prakashan, Ed., in Proceedings of the 7th Symposium on Earthquake Engineering, vol. 1, pp. 267-277pp. 267-, Meerut, India, 1982.

[11] K. M. McMullin and D. S. Merrick, "Seismic damage thresholds for gypsum wallboard partition walls," Journal of Architectural Engineering, vol. 13, no. 1, pp. 22-29, 2007.

[12] L. Reynaud, E. Josh, and J. Melissa, "Static racking behavior of plywood, OSB, gypsum, and fiber bond walls with metal framing," Journal of Structural Engineering, vol. 123, no. 8, pp. 1079-1087, 1997.

[13] T.-H. Lee, M. Kato, T. Matsumiya, K. Suita, and M. Nakashima, "Seismic performance evaluation of nonstructural components: drywall partitions," Earthquake Engineering \& Structural Dynamics, vol. 36, no. 3, pp. 367-382, 2007.

[14] R. Retamales, R. Davies, G. Mosqueda, and A. Filiatrault, "Experimental seismic fragility of cold-formed steel framed gypsum partition walls," Journal of Structural Engineering, vol. 139, no. 8, pp. 1285-1293, 2013.

[15] R. D. Davies, "Seismic evaluation, parameterization, and effect of light-frame steel studded gypsum partition walls," ProQuest Dissertations Publishing, Buffalo, NY, USA, Theses, 2010.

[16] D. A. Padilla-Llano, C. D. Moen, and M. R. Eatherton, "Cyclic axial response and energy dissipation of cold-formed steel framing members," Thin-Walled Structures, vol. 78, pp. 95107, 2014. 
[17] S. Amer, S. Hamoush, and T. Abu-Lebdeh, "In-plane performance of gypsum board partition wall systems subjected to cyclic loadings," Journal of Constructional Steel Research, vol. 124, pp. 23-36, 2016.

[18] E. Rahmanishamsi, S. Soroushian, and E. M. Maragakis, "Analytical model for the in-plane seismic performance of cold-formed steel-framed gypsum partition walls," Earthquake Engineering \& Structural Dynamics, vol. 45, no. 4, pp. 619-634, 2016.

[19] E. Rahmanishamsi, S. Soroushian, and M. Emmanuel, "Maragakis. capacity evaluation of typical track-to-concrete power-actuated fastener connections in nonstructural walls," Journal of Structural Engineering, vol. 142, no. 6, pp. 1-15, 2016.

[20] E. Rahmanishamsi, S. Soroushian, and M Emmanuel, "Maragakis. evaluation of the out-of-plane behavior of studto-track connections in nonstructural partition walls," ThinWalled Structures, vol. 103, pp. 211-224, 2016.

[21] E. Rahmanishamsi, S. Soroushian, and M Emmanuel, "Maragakis. capacity evaluation of typical stud-track screw connections in nonstructural," Journal of Earthquake Engineering, vol. 20, no. 6, pp. 931-953, 2016.

[22] C. Jenkins, S. Soroushian, E. Rahmanishamsi, and E. M. Maragakis, "Experimental fragility analysis of coldformed steel-framed partition wall systems," Thin-Walled Structures, vol. 103, no. 4, pp. 115-127, 2016.

[23] Z. Fangxu, Research on Experimental Fragility and Hysteretic Behavior of Cold-Formed Steel Gypsum Sheathed Partition Walls, pp. 9-12, Harbin Institute of Technology, Harbin, China, 2018, in Chinese.

[24] China Institute of Building, Standard Design and Research, Light Steel Keel Gypsum Board Partition Wall and Suspended Ceiling Standard 07CJ03-1, China Planning Press, Beijing, China, 2007, in Chinese.

[25] R. Retamales, G. Mosqueda, A. Filiatrault, and A. Reinhorn, "Testing protocol for experimental seismic qualification of distributed nonstructural systems," Earthquake Spectra, vol. 27, no. 3, pp. 835-856, 2011.

[26] K. Porter, R. Kennedy, and R. Bachman, "Creating fragility functions for performance-based earthquake engineering," Earthquake Spectra, vol. 23, no. 2, pp. 471-489, 2007. 